\title{
Pengembangan Modul Autentikasi Captcha Berbasis Gambar dengan Algoritma Flood Fill
}

\author{
Jessika Wandapranata ${ }^{1)}$, Seng Hansun ${ }^{2)}$ \\ ${ }^{1) 2)}$ Program Studi Teknik Informatika, Fakultas Teknik dan Informatika, \\ Universitas Multimedia Nusantara \\ Jl. Scientia Boulevard, Gading Serpong, Tangerang, Banten-15811 Indonesia \\ 1)jessika.wandapranata@student.umn.ac.id \\ ${ }^{2)}$ hansun@umn.ac.id
}

\begin{abstract}
$\overline{\text { Abstrak-Captcha merupakan salah satu cara memberikan akses internet yang aman dari serangan bots. }}$ Captcha (Completely Automated Public Turing Test To Tell Computers and Humans Apart) merupakan sebuah challenge response test yang digunakan untuk membedakan manusia dan robot (bots). Namun seiring perkembangan waktu, telah berkembang serangan otomatis yang berhasil membobol beberapa jenis Captcha. Oleh karena itu, pada penelitian ini dikembangkan Captcha berbasis gambar dengan metode autentikasi yang berbeda. Autentikasi Captcha dilakukan dengan menerapkan algoritma Flood Fill. Dalam implementasinya, dapat disimpulkan bahwa algoritma Flood Fill berhasil diimplementasikan pada autentikasi modul Capthca berbasis gambar. Telah dilakukan juga pengumpulan sampel data dan didapatkan hasil $\mathbf{7 7 . 4 \%}$ responden merekomendasikan penggunaan Captcha yang telah dibangun.
\end{abstract}

Kata Kunci- Autentikasi, Captcha, Captcha Berbasis Gambar, Flood Fill

Abstract-Captcha is one of many methods to secure internet from bots attack. Captcha (Completely Automated Public Turing Test To Tell Computers and Humans Apart) is a challenge response test which used to differentiate human from bots. However after the times flow, some hackers had successfully made an automatic bots to break captcha. Therefore, in this particular research, formed an imaged based captcha that uses different method of authentication. Flood Fill algorithm will be used as authentication method. In the implementation, Flood Fill algorithm has been successfully implemented as an authentication method in image based captcha. After that, data samples have been collected and the result shows $\mathbf{7 7 . 4 \%}$ respondents agreed to recommend using the Captcha that has been developed.

Keywords-Authentication, Captcha, Image-based Captcha, Flood Fill

Article history:

Received 6 October 2016; Received in revised form 14 November 2016; Accepted 15 December 2016; Available online 28 April 2017

\section{PENDAhUluan}

Banyak serangan yang terjadi dalam internet, salah satu serangan yang cukup marak ditemui adalah serangan bots (Saini \& Bala, 2013). bots merupakan program komputer yang melakukan pekerjaan-pekerjaan otomatis yang bertujuan buruk seperti menghabiskan resource yang menyebabkan user tidak dapat menggunakannya, memasukkan data yang tidak valid, ataupun melakukan spamming (Saini \& Bala, 2013) (Datta, Li, \& Wang, 2005). Captcha merupakan salah satu solusi untuk mengatasi bots. Captcha (Completely Automated Public Turing Test To Tell Computers and Humans Apart) merupakan sebuah challenge response test yang digunakan untuk membedakan manusia dan robot (bots). Captcha dapat diklasifikasikan menjadi text-based Captcha, image-based Captcha, audio-based Captcha, dan video-based Captcha (Saini \& Bala, 2013).

Image-based Captcha memiliki kelebihan karena pattern recognition merupakan sebuah permasalahan yang sulit dipecahkan oleh kecerdasan buatan sehingga sulit membobol test yang menggunakan teknik pattern recoginition dengan bots (Singh \& Pal, 2014). Selain itu, manusia memiliki kemampuan yang lebih baik dalam mengenali bentuk dengan berbagai noise yang diberikan dibandingkan dengan komputer (Lin, Huang, Bell, \& Lee, 2011). Berdasarkan penelitian sebelumnya, serangan otomatis terhadap text-based Captcha telah berhasil dilakukan sebesar 20\% terhadap Google's CAPTCHA, 30-35\% terhadap Microsoft's CAPTCHA, dan $35 \%$ terhadap Yahoo! CAPTCHA. Sedangkan serangan terhadap audiobased CAPTCHA milik Google bahkan sekitar 90\% berhasil dipecahkan (Setiawan, 2012).

Berdasarkan masalah yang sudah dijelaskan, ingin dikembangkan Captcha berbasis gambar (image-based Captcha) dengan mekanisme autentikasi berbeda. Pada Captcha ini user akan diminta untuk menghubungkan titik-titik yang diberikan menjadi sebuah bentuk. Setelah itu akan dilakukan pemeriksaan kecocokan bentuk yang telah digambar user menggunakan algoritma Flood Fill. Flood Fill digunakan untuk mengisi daerah pixel dalam batasan tertentu. Pada penelitian ini, nilai-nilai pixel tersebut akan disimpan dalam 
array untuk dilakukan perbandingan apakah nilai berada dalam batas toleransi benar.

\section{TINJAUAN PUSTAKA}

\section{A. Flood Fill}

Algoritma Flood Fill atau yang biasa disebut juga dengan algoritma seed fill, merupakan algoritma yang menentukan area yang terhubung dengan suatu node dalam array multidimensi (Ramadhanus, 2013). Algoritma Flood Fill umumnya diimplementasikan untuk mengisi sebagian area dengan warna tertentu atau mengisi pixel dari sebuah gambar dengan value tertentu (Harsono, 2015). Flood Fill sering digunakan dalam program pengolah gambar bitmap untuk mewarnai suatu daerah terbatas dengan warna tertentu seperti Adobe Photoshop dan Corel Paintshop (Nosal, 2008). (Khalili, 2006) menyatakan bahwa implementasi algoritma Flood Fill dapat ditemukan pada fitur bucket tool dalam piranti lunak pengolahan gambar.

Terdapat berbagai cara implementasi algoritma Flood Fill, tetapi semua menggunakan struktur data stack atau queue, baik secara eksplisit maupun implisit. Penyebaran dalam algoritma ini dapat dilakukan ke empat arah yaitu ke arah timur, selatan, barat, dan utara, maupun ke delapan arah yaitu ke semua arah mata angin, termasuk sisi diagonal (Ramadhanus, 2013). (Vandevenne, 2004) menggambarkan pseudocode dari algoritma Flood Fill dengan metode penyebaran delapan arah menggunakan stack pada Gambar 1.

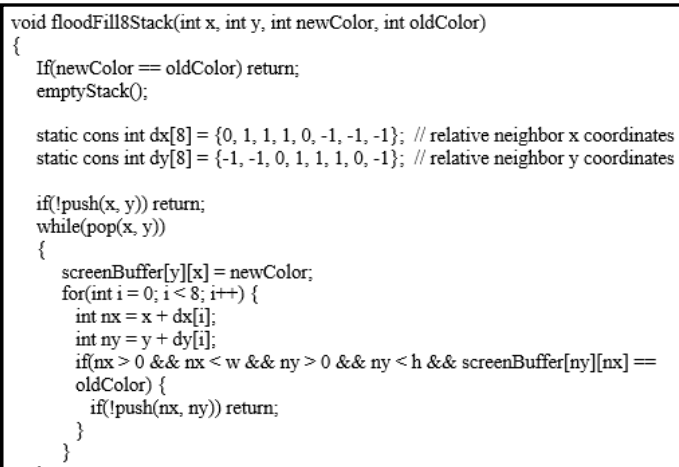

Gambar 1. Potongan pseudocode algoritma Flood Fill

Algoritma Flood Fill menerima input berupa seed pixel (pixel awal dimulainya penyebaran) dan fill color (warna pengisi). Algoritma ini akan dimulai dari seed pixel lalu dilakukan pengecekan ke pixel tetangganya (ke empat arah maupun delapan arah) apakah pixel tersebut memiliki warna seperti warna boundary. Jika tidak, pixel tersebut akan diisi dengan fill color yang telah diberikan sebelumnya. Proses ini akan dilakukan terus-menerus secara rekursif sampai ditemukan pixel yang memiliki warna sesuai warna boundary (Anitha \& Evangeline, 2013).

\section{B. Captcha}

(Saini \& Bala, 2013) menyatakan bahwa Captcha (Completely Automated Public Turing test to tell Computers and Humans Apart) merupakan suatu teknik yang digunakan untuk membedakan manusia dan komputer (bots). Captcha mengikuti turing test terbalik (reverse turing test), pada test tersebut program Captcha bertindak seperti penilai dan partisipan bertindak sebagai user. Jika user dapat melewati test itu, maka user adalah manusia, jika tidak maka user adalah mesin. Captcha diklasifikasikan menjadi beberapa kelompok berdasarkan pada bagian apa dilakukan distorsi, apakah karakter, gambar, suara, atau video.

\section{Drawing Captcha}

Metode menggambar untuk membedakan manusia dan komputer dikembangkan dalam Rujukan (Shirali-Shahreza \& Shirali-Shahreza, 2006). Metode ini bagus untuk digunakan pada perangkat yang memiliki keyboard kecil, atau bahkan yang tidak memiliki keyboard. Cara kerja metode ini adalah dengan menggambar banyak titik secara random di layar, beberapa dari titik tersebut dapat dibedakan dari titik-titik yang lain, misalnya dengan membuat lubang di dalam titik atau menggambar titik dengan bentuk kotak atau berlian. Setelah itu akan ditambahkan beberapa noise dalam gambar dan user akan diminta untuk menghubungkan titik-titik yang berbeda. Drawing Captcha memiliki beberapa kelebihan, diantaranya adalah tidak membutuhkan keyboard, bisa digunakan segala kalangan usia, dan tidak terbatas bahasa tertentu (universal).

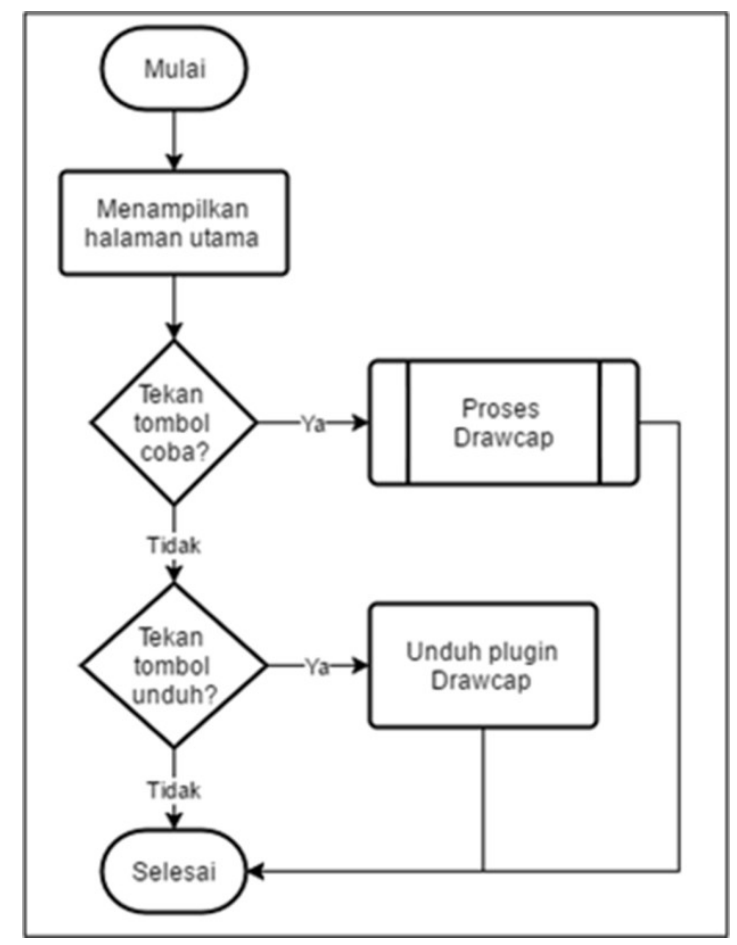

Gambar 2. Diagram alir prosedur halaman utama 


\section{DESKRIPSI DAN PERANCANGAN SISTEM}

\section{A. Deskripsi Sistem}

Aplikasi yang dikembangkan diberi nama Drawcap. Pada aplikasi ini user diminta untuk menghubungkan titik-titik menjadi sebuah bangun datar yang sesuai dengan contoh yang telah diberikan. Bangun datar yang diberikan terdiri dari bangun yang tersusun atas tiga buah titik (segitiga sembarang, segitiga sama kaki, segitiga siku-siku), empat buah titik (persegi, persegi panjang, belah ketupat, layang-layang, jajar genjang, trapesium, trapesium siku-siku, segi empat sembarang), lima buah titik (segi lima, segi lima sembarang), dan enam buah titik (segi enam, segi enam sembarang) yang dipilih secara acak. Distorsi berupa garisgaris dengan berbagai macam pola juga akan diberikan pada contoh gambar bangun.

Saat menjawab Captcha, user akan diberikan tambahan beberapa titik di luar titik-titik penyusun bangun. User harus menentukan mana titik yang harus dihubungkan untuk membentuk bangun seperti pada contoh yang diberikan pada bagian pertanyaan. Akan diberikan batasan waktu pengerjaan Captcha sesuai dengan jumlah titik penyusun bangun. Secara garis besar, aplikasi terdiri dari dua buah bagian utama, yaitu generate Captcha dan validasi Captcha.

\section{B. Perancangan Sistem}

Prosedur sistem akan digambarkan dalam diagram alir. Berikut diberikan beberapa diagram alir dari prosedur pengembangan sistem. Prosedur sistem dimulai dengan menampilkan halaman utama. Pada halaman ini user dapat mencoba mengerjakan Drawcap dengan menekan tombol Coba. Setelah menekan tombol Coba user akan diarahkan ke halaman yang berisi contoh formulir registrasi dan contoh penggunaan Drawcap. Jika ingin mengunduh plugin Drawcap, user dapat menekan tombol unduh pada halaman utama. Diagram alir prosedur ini dapat dilihat pada Gambar 2.

1) Prosedur Proses Drawcap : Prosedur proses Drawcap dimulai dari inisialisasi canvas tempat menampilkan dan menjawab Captcha. Setelah inisialisasi selesai dilakukan, akan dilanjutkan dengan proses generate Captcha secara acak. Jika user ingin mengganti Captcha, user dapat menekan tombol Ulang dan inisialisasi canvas serta proses generate Captcha akan diulang kembali untuk menghasilkan Captcha yang berbeda. Jika user mengalami kesalahan dalam menghubungkan titik, user dapat menghapus garis yang telah digambar dengan menekan tombol Hapus. Saat tombol Hapus ditekan, seluruh isi canvas untuk menjawab Captcha akan dihapus dan titik-titik penyusun bangun serta titik-titik tambahan akan digambar kembali. Jika user menekan tombol Submit atau waktu yang disediakan telah habis, akan dilakukan proses validasi Captcha. Diagram alir prosedur proses Drawcap dapat dilihat pada Gambar 3.

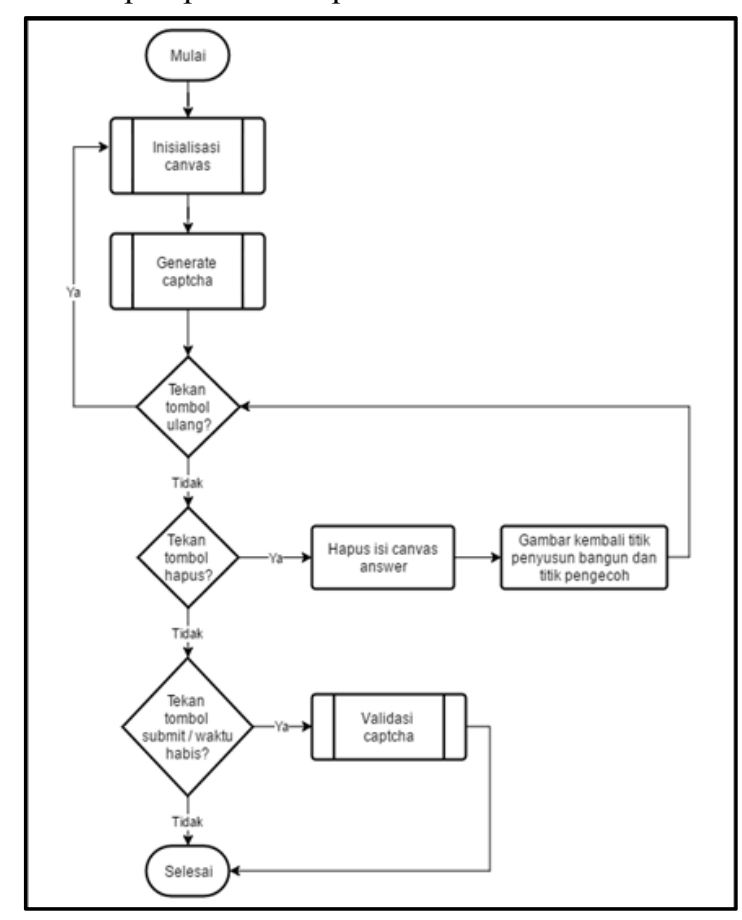

Gambar 3. Diagram alir prosedur proses Drawcap

2) Prosedur Generate Captcha : Prosedur generate Captcha dimulai dengan memilih secara acak sebuah angka yang digunakan untuk menentukan jumlah titik penyusun bangun Captcha. Jumlah titik penyusun bangun menentukan jumlah waktu yang diberikan untuk menyelesaikan Captcha. Setelah itu dilakukan pemilihan angka secara acak kembali untuk menentukan jenis bangun berdasarkan jumlah titik penyusun bangun. Contohnya, jika pada proses pemilihan angka penyusun bangun didapatkan angka tiga maka dilakukan pemilihan angka secara acak untuk menentukan jenis bangun segitiga. Jika didapat angka nol maka dibangun segitiga sembarang, jika didapat angka satu maka dibangun segitiga siku-siku, dan jika didapat angka dua maka dibangun segitiga sama kaki. Selanjutnya dilakukan pemilihan secara acak jumlah titik yang ditambahkan pada canvas jawaban berikut posisinya. Terakhir, dipilih garis dengan pola seperti apa yang akan ditambahkan pada canvas soal sebagai distorsi. Diagram alir prosedur generate Captcha dapat dilihat pada Gambar 4.

Prosedur Flood Fill : Prosedur Flood Fill digunakan dalam perhitungan akurasi Captcha yang dikerjakan user. Pada prosedur ini dilakukan pengecekan warna suatu pixel dalam canvas. Jika warna sama dengan warna awal, maka warna pixel 


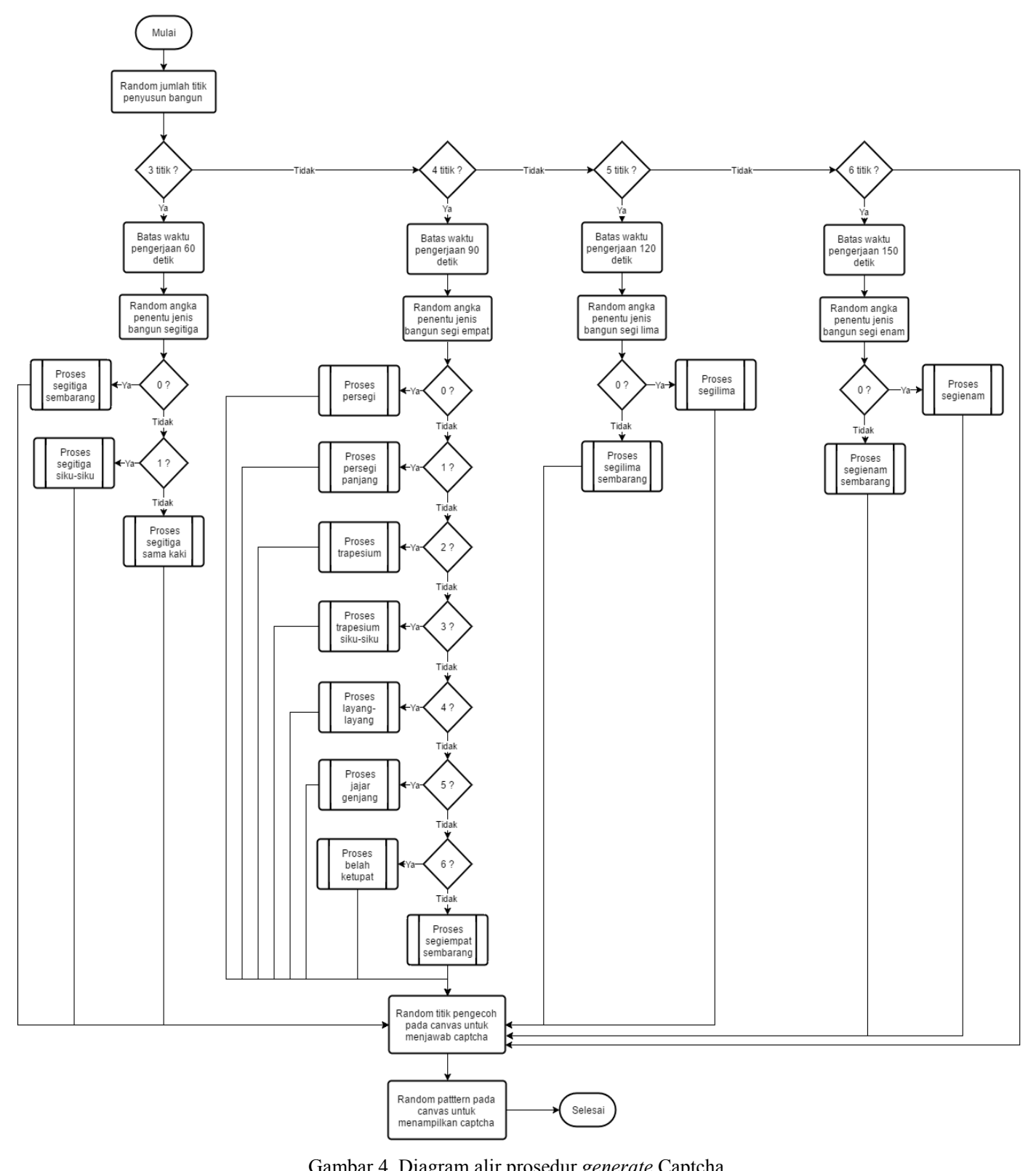

tersebut akan diganti menjadi warna pengganti yang telah ditentukan. Setelah itu, dilakukan penyebaran ke delapan arah sekitar pixel. Selanjutnya dilakukan pengecekan warna yang dimiliki daerah sekitar pixel, jika warna pada daerah tersebut berbeda dengan warna awal, langsung dilakukan pengecekan warna ke daerah sekitar lainnya. Namun jika warna sama, koordinat pixel tersebut akan di-push ke dalam stack untuk selanjutnya dilakukan perubahan warna dan penyebaran ke delapan arah sekitar pixel tersebut. Proses ini akan terus diulangi sampai isi stack kosong. Diagram alir prosedur Flood Fill dapat dilihat pada Gambar 5.

\section{IMPLEMENTASI DAN PEMBAHASAN}

\section{A. Hasil Implementasi}

Modul autentikasi Captcha berbasis gambar selanjutnya dikembangkan sesuai perancangan yang telah dijelaskan pada bab sebelumnya. Gambar 6 memperlihatkan antarmuka utama aplikasi web dimana pengembangan modul autentikasi Captcha ini diterapkan.

Pada halaman Coba Captcha terdapat sebuah form registrasi yang digunakan sebagai contoh penerapan Drawcap. Selain itu terdapat sebuah tombol yang dapat digunakan sebagai trigger untuk memanggil modal berisi Drawcap yang harus diisi. Jika tombol mulai Captcha ditekan, akan muncul sebuah modal yang berisi Drawcap yang harus dikerjakan. Modal terdiri dari tiga bagian, bagian tengah berisi instruksi pengerjaan 


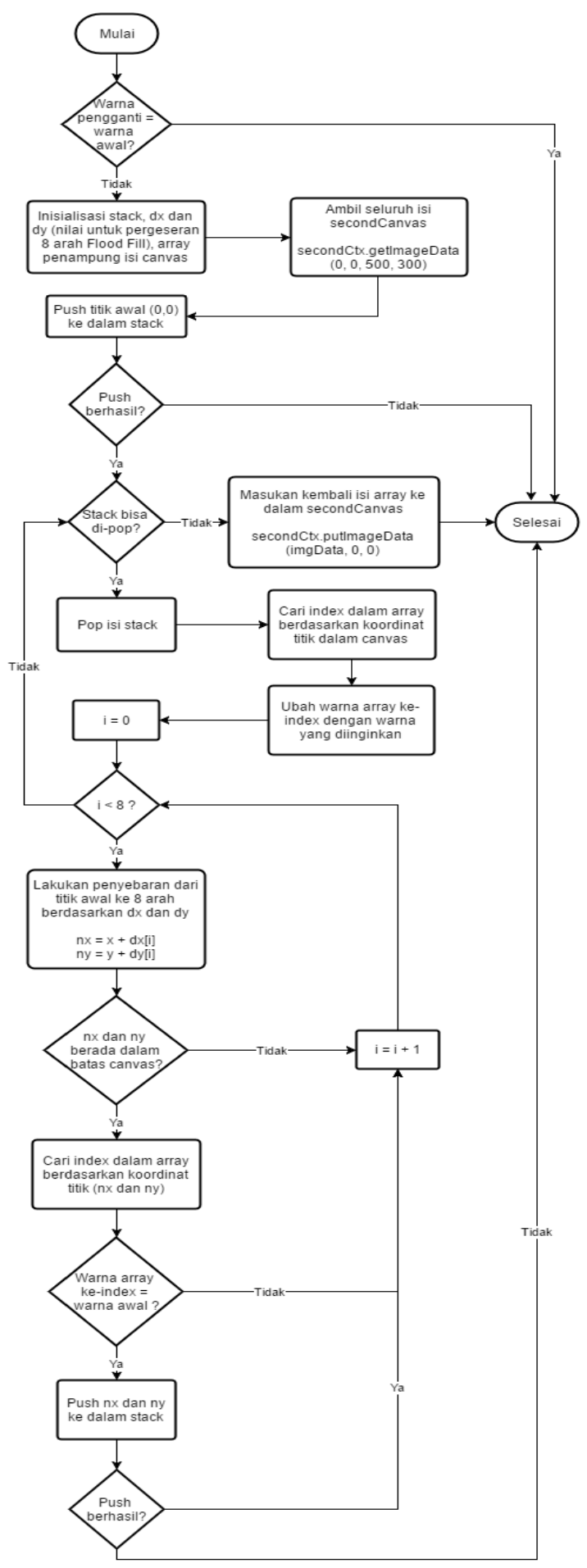

Gambar 5. Diagram alir prosedur Flood Fill

Drawcap beserta timer dan tiga buah tombol yaitu tombol Submit yang digunakan untuk memvalidasi Drawcap yang telah dikerjakan, tombol Hapus yang dapat digunakan jika user melakukan kesalahan dalam menggambar garis untuk menjawab Drawcap, dan tombol Ulang yang dapat digunakan untuk me-refresh Drawcap atau menampilkan Drawcap dengan soal berbeda. Gambar 7 menunjukkan bagian modal Drawcap.

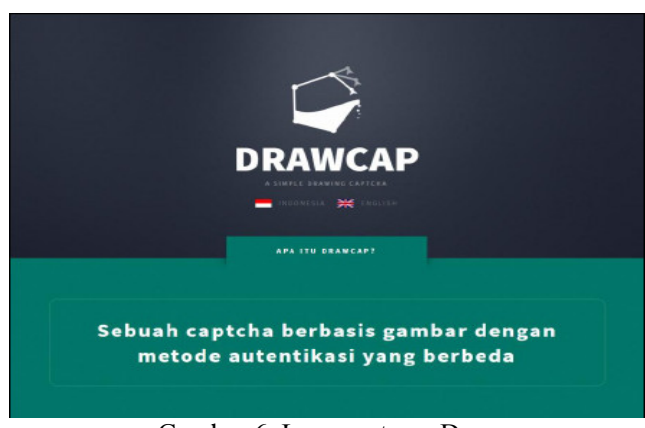

Gambar 6. Laman utama Drawcap

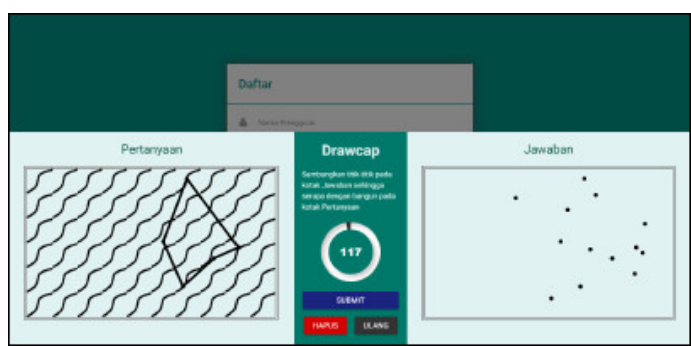

Gambar 7. Modal Drawcap pada laman coba Captcha

Setelah user menekan tombol Submit atau waktu pada timer habis akan dilakukan validasi Drawcap yang dikerjakan. Gambar 8 menunjukkan tampilan modal saat user berhasil lolos validasi Drawcap, sedangkan modal seperti Gambar 9 akan muncul jika user belum berhasil lolos validasi Drawcap.

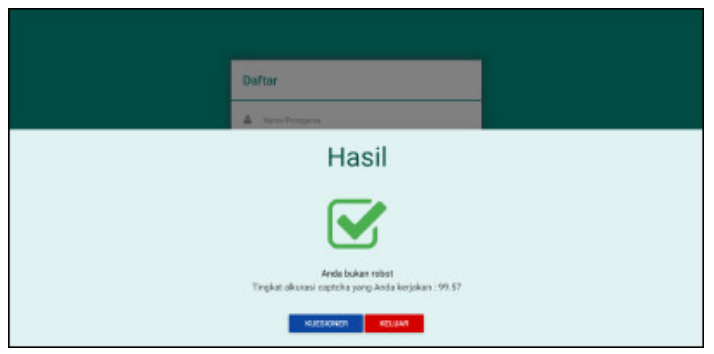

Gambar 8. Tampilan saat user berhasil lolos Drawcap

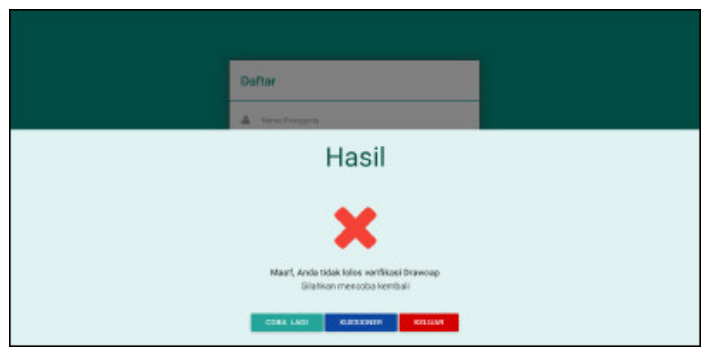

Gambar 9. Tampilan saat user gagal Drawcap

\section{B. Pengujian Threshold dan Evaluasi Sistem}

Setelah aplikasi selesai dibangun, dilakukan pengujian untuk mendapatkan threshold (nilai batas kesalahan) yang digunakan sebagai threshold validasi Captcha saat aplikasi disebarkan untuk mengumpulkan sampel data penelitian. Pengujian dilakukan dengan meminta 
beberapa orang mengerjakan Captcha yang telah dibangun secara berulang-ulang. Captcha dikerjakan sebanyak 150 kali dan dicatat persentase perbedaan gambar user dengan gambar yang harus diikuti pada bagian pertanyaan. Setelah itu, dicari rata-rata persentase kesalahan dari data yang telah dikumpulkan dan didapatkan nilai 0.6 sebagai threshold validasi Captcha.

Setelah didapatkan nilai threshold untuk validasi, dilakukan pengumpulan data untuk analisis lebih lanjut dengan mengunggah aplikasi ke jaringan internet sehingga para relawan dapat melakukan pengujian aplikasi dengan lebih mudah. Analisis yang dilakukan pada sampel data bertujuan untuk mengetahui tingkat kesulitan Drawcap dan kompatibilitas atau penerimaan Drawcap sebagai Captcha berbasis gambar.

Berdasarkan pengumpulan sampel data yang telah dilakukan, didapat 84 data hasil pengisian kuesioner. Berdasarkan data 84 responden, terdapat 33 responden $(39.3 \%)$ menyatakan Drawcap lebih mudah diselesaikan dibanding Captcha lain yang pernah mereka kerjakan dan perhitungan Skala Likert menghasilkan nilai $66.67 \%$ sebagai tingkat kesulitan rata-rata Drawcap. Gambar 10 dan 11 memperlihatkan diagram lingkaran tingkat kesulitan Drawcap dibanding Captcha lainnya dan diagram batang tingkat kesulitan rata-rata Drawcap secara umum berdasarkan responden.

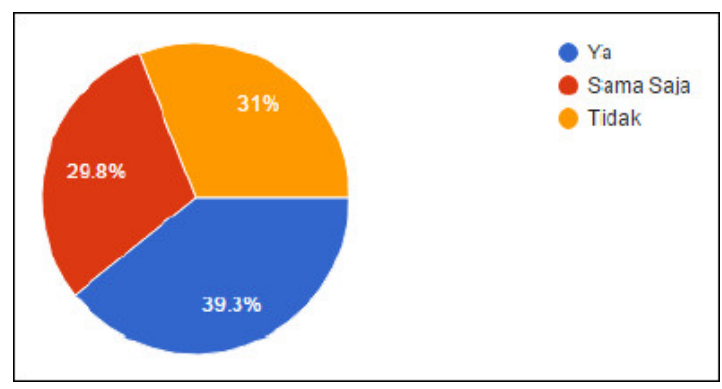

Gambar 10. Tingkat kesulitan Drawcap dibanding Captcha lainnya

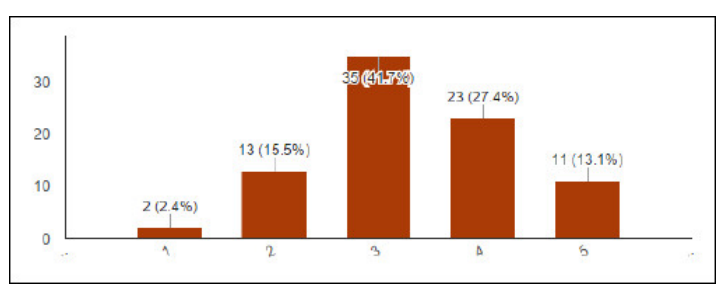

Gambar 11. Tingkat Kesulitan Drawcap

Walaupun Drawcap cukup sulit untuk diselesaikan, perhitungan Skala Likert menghasilkan nilai $82.38 \%$ sebagai tingkat keamanan rata-rata Drawcap menurut responden, yang ditunjukkan oleh Gambar 12. Selain itu, $77.4 \%$ responden merekomendasikan penggunaan Drawcap dibanding Captcha lainnya sebagaimana yang diperlihatkan oleh Gambar 13.

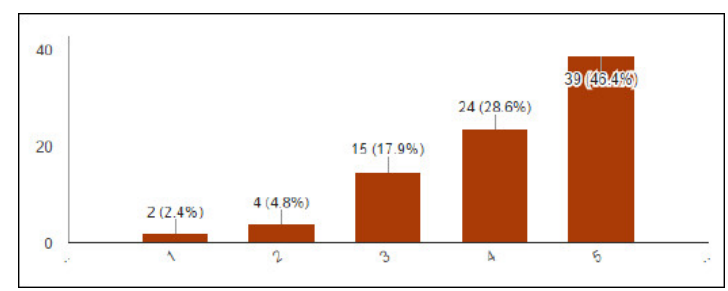

Gambar 12. Tingkat Keamanan Drawcap

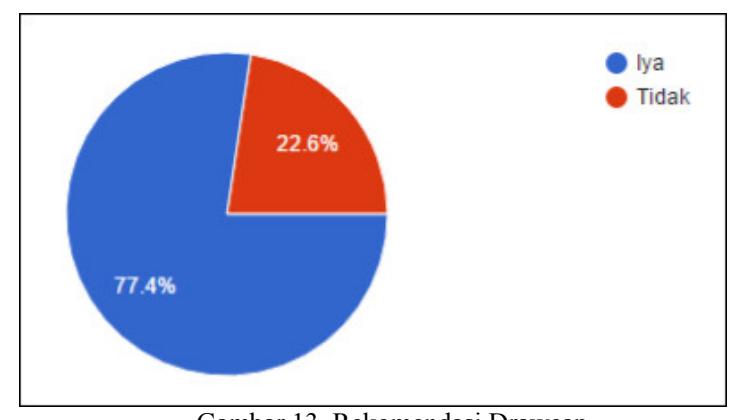

Gambar 13. Rekomendasi Drawcap

\section{KESIMPULAN}

Implementasi algoritma Flood Fill pada autentikasi modul Captcha berbasis gambar telah berhasil dilakukan. Pada implementasi ini, user dapat mencoba mengerjakan Captcha yang telah dibangun dan menggunakannya sebagai plugin. Hasil analisis data yang telah dilakukan terhadap 84 responden menunjukkan bahwa Drawcap memiliki tingkat kesulitan rata-rata $66.67 \%$ dan memiliki tingkat keamanan rata-rata sebesar 82,38\%. Namun demikian, Drawcap direkomendasikan penggunaannya oleh $77.4 \%$ responden mengingat fitur yang ditawarkannya. Pengembangan selanjutnya dapat dilakukan dengan menambah variasi bangun Captcha, meningkatkan cara menghubungkan titik menjadi garis pada perangkat touch screen, dan mengembangkan cara mengenali bentuk bangun, seperti menggunakan deteksi tepi atau fungsi pengolahan gambar lainnya.

\section{DAFTAR PUSTAKA}

Anitha, S., \& Evangeline, D. (2013). An Efficient Fence Fill Algorithm using Inside-Outside Test. International Journal of Advanced Research in Computer science and Software Engineering , 5 (3), 605-609.

Datta, R., Li, J., \& Wang, J. (2005). IMAGINATION: A Robust Image-base CAPTCHA Generation System. Proceedings of the ACM Multimedia Conference (pp. 331-334). Singapore: ACM, The Pennsylvania State University.

Harsono, E. (2015). Implementasi Algoritma Flood Fill pada Aplikasi Ishihara Plate Image Generator. Skripsi, Universitas Multimedia Nusantara, Teknik Informatika.

Khalili, B. (2006). A hybrid format for storing raster images. University of Colorado Boulder, Computer Science. 
Lin, R., Huang, S., Bell, G., \& Lee, Y. (2011). A New CAPTCHA Interface Design for Mobile Device. AUIC '11 Proceedings of the Twelfth Australasian User Interface Conference (pp. 38). Perth: Australian Computer Society.

Nosal, E. (2008). Flood-fill algorithms used for passive account detection and tracking. 2008 New Trends for Environmental Monitoring Using Passive Systems (pp. 1-5). Hyeres: IEEE.

Ramadhanus, A. (2013). Penerapan Algoritma Flood Fill untuk Mengurangi Ruang Pencarian pada Pencarian Solui Puzzle Pentomino. Makalah, Institut Teknologi Bandung, Program Studi Teknik Informatika.

Saini, B., \& Bala, A. (2013). A Review of Bot Protection using CAPTCHA for Web Security. IOSR Journal of Computer Engineering , 8 (6), 36-42.
Setiawan, E. (2012). Optimalisasi Keamanan Website Menggunakan Captcha - Ad Video. Jurnal Ilmiah Komputer dan Infomatika , 1 (1), 1-6.

Shirali-Shahreza, M., \& Shirali-Shahreza, S. (2006). Drawing Captcha. 28th International Conference on Information Technology Interfaces (pp. 475-480). Cavtat: IEEE.

Singh, V., \& Pal, P. (2014). Survey of Different Types of CAPTCHA. International Journal of Computer Science and Information Technologies , 5 (2), 2242-2245.

Vandevenne, L. (2004). Lode's Computer Graphics Tutorial : Flood Fill. Retrieved February 27, 2016,

from http://lodev.org/cgtutor/floodfill.html 